\title{
INFLUENCE OF INITIAL CELL CONCENTRATIONS ON THE GROWTH RATE AND BIOMASS PRODUCTIVITY OF MICROALGAE IN DOMESTIC WASTEWATER
}

\author{
Gani, $P .{ }^{1 *}$-Sunar, N. M. ${ }^{2}$ - Matias-Peralta, $H^{3}{ }^{3}$-Abdul LatifF, A. A. ${ }^{1}$ - Abdul RazaK, A. R. ${ }^{1}$ \\ ${ }^{I}$ Department of Water and Environmental Engineering, Faculty of Civil and Environmental \\ Engineering \\ ${ }^{2}$ Department of Chemical Engineering Technology, Faculty of Engineering Technology \\ ${ }^{3}$ Department of Technology and Heritage, Faculty of Science, Technology and Human \\ Development
}

Universiti Tun Hussein Onn Malaysia, 86400 Parit Raja Batu Pahat, Johor, MALAYSIA. (phone: +607-4537000; fax: +607-4536337)

*Corresponding author

e-mail:parancgat@yahoo.com

(Received $2^{\text {nd }}$ Aug 2015; accepted $2^{\text {nd }}$ Mar 2016)

\begin{abstract}
The aim of this study was to compare the specific growth rate and biomass productivity of microalgae in domestic wastewater according to the initial cell concentration. The initial microalgae cell concentrations tested started from $10^{3}$ cell $/ \mathrm{mL}, 10^{4}$ cell $/ \mathrm{mL}, 10^{5}$ cell $/ \mathrm{mL}, 10^{6}$ cell $/ \mathrm{mL}$, and $10^{7}$ cell $/ \mathrm{mL}$ under outdoor condition. The result revealed that the highest biomass productivity occurred at $10^{6} \mathrm{cel} 1 / \mathrm{mL}$ concentration with a value of $1.24 \times 10^{4} \mathrm{cell} / \mathrm{mL} / \mathrm{day}, 0.26$ day $^{-1}$ of specific growth rate, and a doubling time of 2.63 days. Meanwhile, the lowest biomass productivity occurred at $10^{3}$ cell/mL concentration with the lowest specific growth rate of $0.1 \mathrm{day}^{-1}$ and the longest doubling time, which reached up to 7.14 day. As a result, the initial cell concentration of microalgae did influence the algal biomass productivity and growth rate differently. Thus, the maximum growth rate and biomass productivity were obtained at $10^{6}$ cell/mL concentration which is recommended to be used in biotechnology industries and any wastewater treatment.
\end{abstract}

Keywords: microalgae, growth rate, biomass productivity, wastewater, and cell concentration

\section{Introduction}

Currently, growing microalgae in wastewater has become a topic of interest among researchers worldwide for its potential in phycoremediation, biofuel and hydrocarbon production, greenhouse gases mitigation and other factors (Gani, et al., 2015a; Gani, et al., 2015b; Onalo et al., 2014; Komolafe, et al., 2014; Rasoul-Amini et al., 2014; Lim and Vadivelu, 2014; Prakash et al., 2014; Shin et al., 2015; Abdelaziz et al., 2014; Mehrabadi et al., 2014; Slade and Bauen, 2013; Guo et al., 2013; Kothari et al., 2012; Park et al., 2011). The success of culturing mostly depends on the availability of nutrients in wastewater, culturing techniques, and environmental factors such as light, temperature, salinity, pH, and photoperiod (Komolafe, et al., 2014; Cai et al., 2013; Udom et al., 2013; Zhu et al., 2013; Sacristán de Alva et al., 2013; Kothari et al., 2013; Mata et al., 2012; Asulabh et al., 2012; Kirrolia et al., 2012; Qin and Li, 2006). The uniqueness of microalgae is that they like ordinary crops. In this case, microalgae absorb $\mathrm{CO}_{2}$ in the atmosphere while producing $\mathrm{O}_{2}$ by assimilating nutrients in wastewater (Muñoz and Guieysse, 2006; Mata et al., 2010; Rawat et al., 2011; Brennan 
and Owende, 2010; Abdel-Raouf et al., 2012; Sivakumar and Rajendran, 2013; Slade and Bauen, 2013; Ramachandra et al., 2013; Gani, et al., 2015c). For example, nutrients taken up by microalgae in wastewater such as nitrogen, phosphorus, and carbon are able to reduce eutrophication in aquatic environments (Karthikeyan et al., 2012; Choul-gyun 2002; Chu et al., 2014; Aslan and Kapdan, 2006; Rasoul-Amini et al., 2014; Boonchai et al., 2012; Kim et al., 2013; Valley et al., 2012; Can et al., 2013).

As discussed by Oswald (1957) and De la Noüe et al. (1992), there are many species of algae in nature, some of which has already been grown by other researchers using wastewater as the alternative to synthetic media, such as Chlorella sp., Scenedesmus sp., Spirulina sp., and others. For example, Mata et al. (2012) cultivated Scenedesmus obliquus in synthetic brewery wastewater to analyse the potential of biomass production. They found that the maximum dry biomass was $0.9 \mathrm{~g}$ per litre of culture. In the same study, Scenedesmus obliquus successfully reduced the value of COD and TN up to $57.5 \%$ and $20.8 \%$, respectively. Other than that, Zhu et al. (2013) has successfully grown freshwater microalgae (Chlorella zofingiensis) in piggery wastewater to characterize the algal growth and nutrients removal. Their study used a column photobioreactor with varying nutrient concentration and found that biomass productivity was different subject to several concentrations. Also, Kothari et al. (2013) used dairy industry wastewater for the cultivation of Chlamydomonas polypyrenoideum on biodiesel production. Results indicated that dairy wastewater was a great medium for algae growth when $75 \%$ concentration was applied. Meanwhile, culturing Botryococcus braunii in urban wastewater was studied by Can et al. (2013). The author found that the best growth using different loading concentrations also occurred in $75 \%$ urban wastewater, while without dilution $(100 \%)$ the urban wastewater was better in terms of lipid production.

Although many researchers have investigated microalgae Botrycococcus sp., a few of them focused on synthetic medium (Eroglu et al., 2011; Molnár et al., 2012; Wang et al., 2014; Dayananda et al., 2005; Cheng et al., 2013; Ashokkumar and Rengasamy, 2012; Suzuki et al., 2013) compared to domestic wastewater as the medium (Can et al., 2013; Órpez et al., 2009). So it is necessary to perform deeper research on Botryococcus $\mathrm{sp}$. to be grown in domestic wastewater for the potential of biomass production. The aim of this paper is to compare the specific growth rate and biomass productivity of Botryococcus sp. in domestic wastewater according to the initial cell concentration, while the raw characteristics of domestic wastewater are also determined.

\section{Materials and Methods}

\section{Preparation of microalgae}

Microalgae used in this experiment were collected and isolated from a tropical rainforest in the Southern region of Peninsular Malaysia (between N $02^{\circ} 30.711^{\prime \prime}$ E $103^{\circ} 20.984$ " and $\mathrm{N} \mathrm{02}{ }^{\circ} 30.740 " \mathrm{E} 103^{\circ}$ 20.996"), namely Botryococcus sp. Initial stock cultures of Botryococcus sp. were maintained in modified Bold's Basal medium (Bischoff and Bold, 1963) containing the following chemicals: $\mathrm{NaNO} 3, \mathrm{CaCl} 2.2 \mathrm{H} 2 \mathrm{O}, \mathrm{MgSO} 4.7 \mathrm{H} 2 \mathrm{O}$, K2HPO4, KH2PO4, NaCl, EDTA, KOH, FeSO4.7H2O, H2SO4 and micronutrients ( $\mathrm{ZnSO} 4.7 \mathrm{H} 2 \mathrm{O}, \mathrm{MnCl} 2.4 \mathrm{H} 2 \mathrm{O}, \mathrm{MoO} 3, \mathrm{CuSO} 4.5 \mathrm{H} 2 \mathrm{O}$ and $\mathrm{Co}(\mathrm{NO} 3) 2.6 \mathrm{H} 2 \mathrm{O})$. The culture was inoculated in outdoor condition for 14 days. Prior to inoculation, microalgae cultures were harvested using a centrifuge at low speed (3500rpm) for ten minutes and washed three 
times with sterilized distilled water. This was followed by cell observation and cell concentration count using Neubauer haemocytometer.

\section{Sampling and characterization of wastewater}

The wastewater used in this study was effluent wastewater obtained from a domestic wastewater treatment plant located in Batu Pahat, Johor, Malaysia. The samples were collected in the morning at around 7:00am to 9:00am using acid washed sample bottles at the site and immediately transferred to the laboratory and preserved at temperatures below $4^{\circ} \mathrm{C}$ in a refrigerator. Then, wastewater quality parameters were immediately characterized once the samples reached the laboratory to avoid changes due to chemical and biological reactions. Chemical oxygen demand (COD), biochemical oxygen demand (BOD), total phosphorus (TP), dissolved oxygen (DO), and $\mathrm{pH}$ analysis were measured according to the standard methods (APHA, 2012). While total nitrogen (TN), total organic carbon (TOC), total carbon (TC), and inorganic carbon (IC) were obtained using TOC Analyzer (Brand: TOC-VCSH, Japan, Shimadzu). Before the inoculation process, the wastewater sample was filtered using a nylon membrane filter (Whatman) with a $0.45 \mu \mathrm{m}$ pore size to remove other microorganisms and suspended solids.

\section{Experimental setup}

A total of 15 Erlenmeyer flasks $(500 \mathrm{~mL})$ were filled with $200 \mathrm{~mL}$ wastewater and were used in this experiment as the domestic wastewater. The wastewater experiment flasks (triplicate) were inoculated with microalgae starting with an initial cell concentration of $10^{3}$ cells $/ \mathrm{mL}$ based on the standard methods (APHA, 2012) and increased up to $10^{7}$ cell $/ \mathrm{mL}\left(10^{3}\right.$ cell $/ \mathrm{mL}, 10^{4}$ cell $/ \mathrm{mL}, 10^{5}$ cell $/ \mathrm{mL}, 10^{6}$ cell $/ \mathrm{mL}$, and $10^{7}$ cell $/ \mathrm{mL}$ ) (Kothari et al., 2013). The flasks were covered with sterile cotton plugs and kept under outdoor natural condition during the experimental period. All samples were shaken from time to time to ensure that the Botryococcus sp. was uniformly homogenized in the wastewater.

\section{Determination of microalgae growth}

The samples were taken daily from the culture for cell growth counting in wastewater started on day 3 using Haemocytometer (improved Neubauer chamber) according to Andersen's (2005) technique. The growth of Botryococcus sp. was determined according to the specific growth rate $(\mu /$ day), division per day (Dd), doubling time (td), and biomass productivity (cell/mL/day) using equations $1,2,3$, and 4, respectively (Zhu et al., 2013; Komolafe et al., 2014; Asmare et al., 2013; Issarapayup et al., 2009; Wang et al., 2010; Andersen 2005). Nf and Ni were defined as the cell concentration (cell. $\mathrm{mL}^{-1}$ ) at time $\mathrm{Tf}$ and $\mathrm{Ti}$, respectively. The graph over time was required to plot the growth of batch culture to predict the exponential stage of the culture. At least three-time points were considered to satisfy or confirm the exponential stage (Andersen, 2005).

$$
\begin{gathered}
\text { Specific growth rate }(\mu / \text { day })=\frac{\ln (\mathrm{Nf} / \mathrm{Ni})}{\mathrm{Tf}-\mathrm{Ti}} \\
\text { Division per day }(\mathrm{Dd})=\frac{\mu / \mathrm{day}}{\ln 2}
\end{gathered}
$$




$$
\begin{gathered}
\text { Doubling time }(\mathrm{td})=\frac{1}{\mathrm{Dd}} \\
\text { Biomass productivity }=\frac{\mathrm{Nf}-\mathrm{Ni}}{\mathrm{Tf}-\mathrm{Ti}}
\end{gathered}
$$

\section{Statistical analysis}

All experiments were conducted in triplicates for each culture. Data analysis of average, mean differences, standard deviation, and the graph for each experiment were done using Microsoft Office Excel Professional Plus 2010.

\section{Results and Discussion}

\section{Wastewater characterization}

Wastewater characterization is compulsory and important for determining the nutrient supplements required for microalgae growth during the cultivation process. Table 1 shows the physical and chemical parameters of domestic wastewater compared to the effluent standard which has been used in the formation of culture media in microalgae growth experiments. Concentrations of COD and BOD were $76.1 \mathrm{mg} / \mathrm{L}$ and $44 \mathrm{mg} / \mathrm{L}$, respectively; this concentration was different from that used in other research papers. For example, Mostafa et al. (2012) used untreated domestic wastewater containing $50 \mathrm{mg} / \mathrm{L} \mathrm{COD}$ and $15 \mathrm{mg} / \mathrm{L}$ of BOD to cultivate cyanobacteria and Chlorella vulgaris. Zhang et al. (2013) cultivated mixotrophic microalgae strains in domestic wastewater containing $142 \mathrm{mg} / \mathrm{L}$ of COD. However, the concentration of both COD and BOD in this study remains still under the limit of Standard B but slightly over the limit of Standard A. The wastewater used also contained $3.27 \mathrm{mg} / \mathrm{L}$ of TP, which was below both standard limits, while TN was $15.79 \mathrm{mg} / \mathrm{L}$. Both parameters were compared to a study conducted by Zhang et al. (2013), who found that TP and TN were $1.59 \mathrm{mg} / \mathrm{L}$ and $27.7 \mathrm{mg} / \mathrm{L}$, respectively. Other parameters were also determined such as TSS and TOC in which the values were $2250 \mathrm{mg} / \mathrm{L}$ and $21.06 \mathrm{mg} / \mathrm{L}$, respectively. TSS concentration indicates that the wastewater was incomparable to the effluent standard limit, which was more than $100 \mathrm{mg} / \mathrm{L}$ of Standard B. Other than that, the $\mathrm{pH}$ value showed acceptable concentration compared to the effluent standard and suitable enough for microalgae cultivation (Creswell, 2010).

A few researchers (Zhang et al., 2013; Teles et al., 2013; Can et al., 2013; Ji et al., 2013) have shown the potential of microalgae in domestic wastewater treatment to biotransform pollutants into valuable biomass before the discharge of the cleaned water to the environment. As previously discussed in the introduction, the growth efficiency of microalgae in wastewater mostly depends on different variable factors such as the availability of nutrients and the influence of environmental factors. Thereby, this study may allow the use of domestic wastewater for the development of culture method in biomass production and for further purposes of phycoremediation study coupled with hydrocarbon production. 
Table 1. Characteristics of the raw domestic wastewater used as the growth media

\begin{tabular}{lccc}
\hline Physiochemical parameters & $\begin{array}{c}\text { Concentration } \\
\left({ }^{\mathbf{a}} \mathbf{m g} / \mathbf{L}\right)\end{array}$ & \multicolumn{2}{c}{$\begin{array}{c}\text { Effluent standard, mg/L } \\
\text { (Environmental Quality Act, } \\
\text { 1974) }\end{array}$} \\
\cline { 3 - 4 } & & 50 & Standard B \\
\hline Chemical oxygen demand (COD) & 76.10 & 20 & 50 \\
Biochemical oxygen demand (BOD) & 44.00 & 5 & 10 \\
Total phosphorus (TP) & 3.27 & - & - \\
Total nitrogen (TN) & 15.79 & 50 & 100 \\
Total suspended solid (TSS) & 2250 & - & - \\
Total dissolved solid (TDS) & 4900 & - & - \\
Total carbon (TC) & 21.06 & - & - \\
Total organic carbon (TOC) & 2.19 & - & - \\
Inorganic carbon (IC) & 18.86 & - & - \\
Dissolved oxygen (DO) & 14.76 & $6.0-9.0$ & $5.5-9.0$ \\
pH & 6.93 & & \\
\hline All & & &
\end{tabular}

${ }^{\mathrm{a}}$ All parameters unit in $\mathrm{mg} / \mathrm{L}$ except for $\mathrm{pH}$

*All experiments conducted in triplicate $(n=3)$

\section{Growth of Botryococcus sp. and biomass productivity}

In general, for most experiments, the growth curve which showed existing lag phase and the exponential phase was then followed by gradually increasing the biomass concentration over time except for $10^{7}$ cell/mL concentration. There were no growth activities in this cell concentration due to the overpopulation. However, in other cell concentration experiments, a stationary and declining phases were also observed. All of the above explanations could be referred further in Figure 1 below. Similar growth curve has been reported by Can et al. (2013); Cabanelas et al. (2013); Teles et al. (2013) and Chaput et al. (2012), who used domestic wastewater to grow microalgae but with different nutrients and pollutant load concentrations.

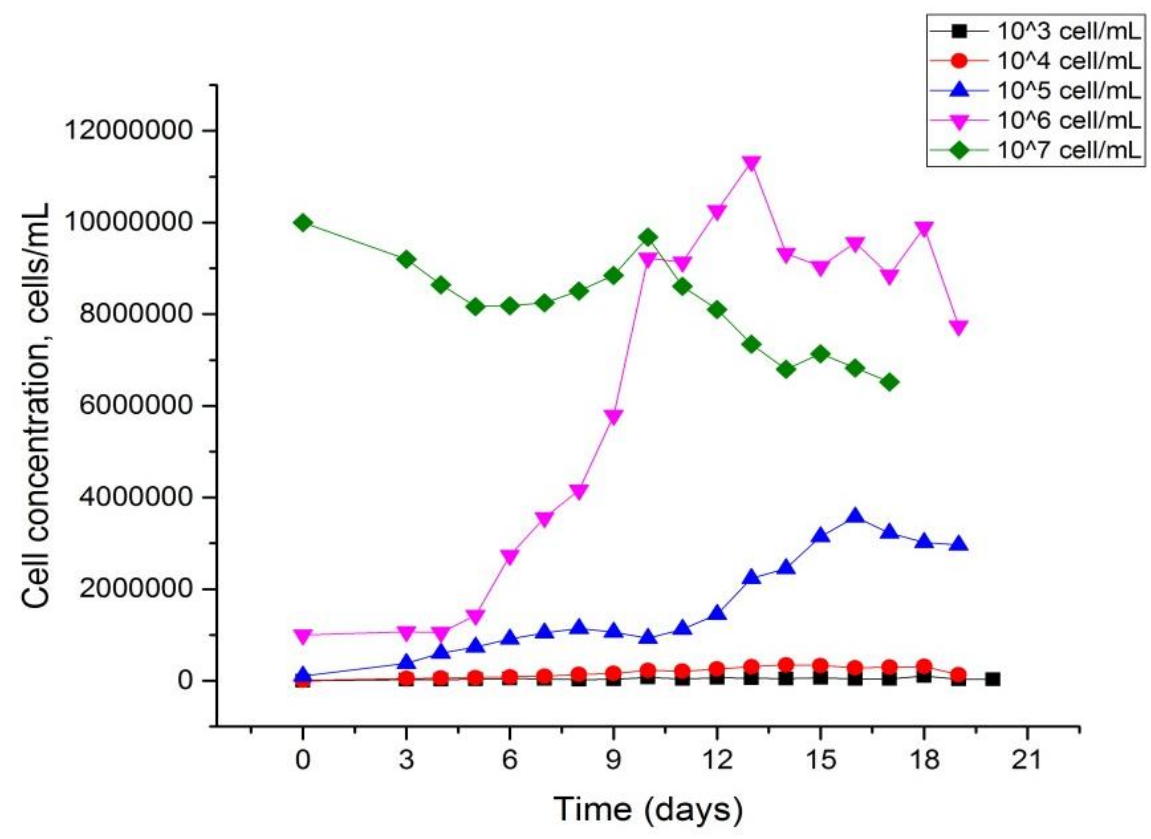

Figure 1. Growth of Botryococcus sp. in different cells concentration 
Obviously, Figure 1 shows that the growth in $10^{6}$ cell $/ \mathrm{mL}$ concentration was enhanced dramatically compared to other cell concentrations such as $10^{3}$ cell/mL and $10^{4}$ cell $/ \mathrm{mL}$ while $10^{5}$ cell $/ \mathrm{mL}$ seemed to show us a better increment but still lower than $10^{6}$ cell $/ \mathrm{mL}$. This means that the maximum peak growth for both cell concentration, $10^{5}$ cell $/ \mathrm{mL}$ and $10^{6}$ cell $/ \mathrm{mL}$, occurred on day 16 at $3.57 \times 10^{6}$ cell $/ \mathrm{mL}$ and day 13 at $1.1 \times 10^{7}$ cell $/ \mathrm{mL}$, respectively.

The exponential phase of Botryococcus sp. growth could be predicted by drawing a straight line in Figure 1, in which the points touched the straight line at least thrice according to Andersen's (2005) technique for each cell concentration except $10^{7}$ cell $/ \mathrm{mL}$. Based on the $10^{6}$ cell $/ \mathrm{mL}$ concentration curve, the exponential phase occurred starting from day 5 to day 13 while for $10^{5}$ cell $/ \mathrm{mL}$ concentration the exponential phase started from day 11 to day 16. Also, according to the data in Figure 1, it was apparent that $10^{3}$ cell $/ \mathrm{mL}$ and $10^{4}$ cell $/ \mathrm{mL}$ concentration showed much less growth, with a maximum cell density achieved of only up to $1 \times 10^{5}$ cell $/ \mathrm{mL}$ and $3.5 \times 10^{5} \mathrm{cell} / \mathrm{mL}$, respectively. Table 2 below thoroughly describes their biomass productivity.

Table 2. Computation of specific growth rate ( $\mu /$ day), division per day $(D d)$, doubling time (td) and biomass productivity of Botryococcus sp. grown on domestic wastewater

\begin{tabular}{ccccc}
\hline $\begin{array}{c}\text { Cell concentration } \\
(\mathbf{C e l l} / \mathbf{m L})\end{array}$ & $\begin{array}{c}\text { Specific growth } \\
\text { rate }(\boldsymbol{\mu} / \mathbf{d a y})\end{array}$ & $\begin{array}{c}\text { Division per } \\
\text { day }(\mathbf{D d})\end{array}$ & $\begin{array}{c}\text { Doubling Time, } \\
\text { td }(\mathbf{d a y})\end{array}$ & $\begin{array}{c}\text { Biomass } \\
\text { productivity, } \\
\text { Cell/mL/day }(\mathbf{1 0})\end{array}$ \\
\hline $1 \times 10^{3}$ & 0.10 & 0.14 & 7.14 & 0.51 \\
$1 \times 10^{4}$ & 0.18 & 0.26 & 3.85 & 3.48 \\
$1 \times 10^{5}$ & 0.23 & 0.33 & 3.03 & 48.98 \\
$1 \times 10^{6}$ & 0.26 & 0.38 & 2.63 & 123.77 \\
$1 \times 10^{7}$ & 0 & 0 & 0 & 0 \\
\hline
\end{tabular}

*All experiments conducted in triplicate $(n=3)$

After identifying the exponential phase, the specific growth rate $(\mu /$ day), doubling time (day), and biomass productivity (cell/mL/day) were determined scientifically based on the formula given in the methodology section in this paper. Table 2 shows that the highest specific growth rate was at $10^{6}$ cell $/ \mathrm{mL}$ concentration with 0.26 day $^{-1}$ compared to other concentrations. So, this result is quite similar to the results obtained by Teles et al., (2013) with specific growth rate value up to 0.23 day $^{-1}$ when cultivating Chlorella vulgaris in domestic wastewater. Then, the lowest specific growth rate occurred at $10^{3}$ cell $/ \mathrm{mL}$ concentration with $0.1 \mathrm{day}^{-1}$ as expected. Biomass productivity results are also provided in Table 2 and have been plotted in a graph over cell concentration compared to specific growth rate in Figure 2.

From the data illustrated in Figure 2, obviously in various cell concentrations, biomass productivity, and the growth rate of Botryococcus sp. were very different. According to Figure 2, it occurred on $10^{6}$ cell $/ \mathrm{mL}$ (x-axis) concentration with the maximum biomass productivity and specific growth rate were $1.24 \times 10^{6}$ cell $/ \mathrm{mL} /$ day and 0.26 day $^{-1}$, respectively; this finding is different from other previous research paper. For example, Shin et al. (2015) used Scenedesmus bijuga for growth on diluted food wastewater and was able to achieve biomass productivity between $39.4 \mathrm{mg} / \mathrm{L} /$ day to $50.75 \mathrm{mg} / \mathrm{L} /$ day in terms of dried weight. This difference is likely due to the strength of nutrients concentration available in the wastewater used. It may also be affected by environment factors, particularly weather conditions. 


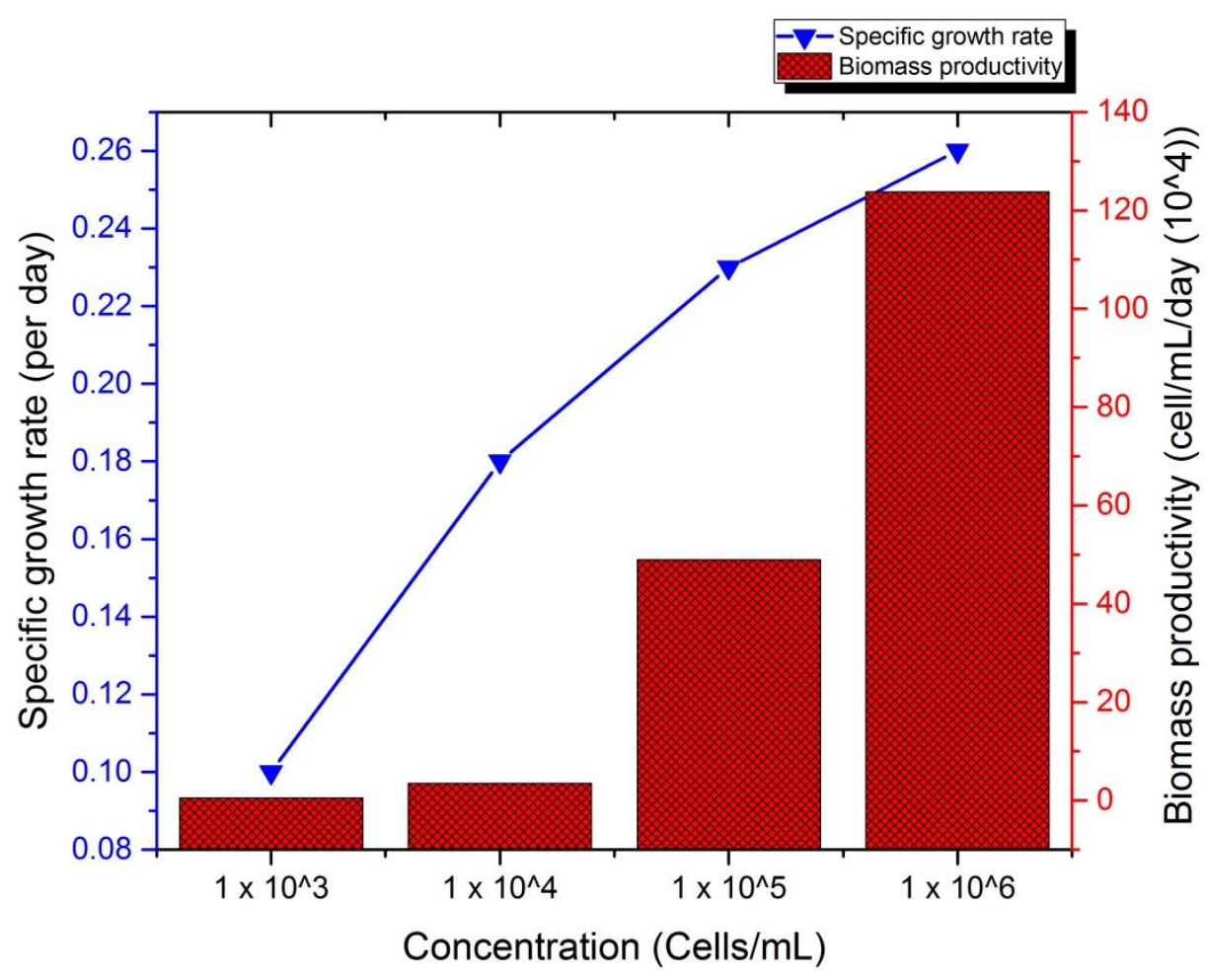

Figure 2. Specific growth rate ( $\mu /$ day) and biomass productivity (cell/mL/day) of Botryococcus sp. in different cell concentration (cell/mL) on domestic wastewater

\section{Conclusion}

Recently, interest in cultivating microalgae as a source of biomass has grown. Growing microalgae requires a large quantity of water and nutrients. Amazingly, the use of domestic wastewater to cultivate microalgae is good from a sustainability perspective. However, the success of culturing microalgae in domestic wastewater is highly dependent on cell concentration at the initial stage of cultivation. This study has demonstrated how different cell concentration of microalgae makes it possible to produce microalgae biomass with high levels of productivity. Further research in this field regarding the role of microalgae Botryococcus sp. would be helpful for phycoremediation and hydrocarbon production.

Acknowledgements. The authors thank the support of any parties involved in this project especially University Tun Hussein Onn Malaysia for providing the equipment and research facilities to carry out this project. Special thanks go also to MyBrain15 Scheme for the research grant sponsorship and other team members.

\section{REFERENCES}

[1] Abdelaziz, A.E.M., Leite, G.B., Belhaj, M.A., Hallentbeck, P.C. (2014): Screening microalgae native to Quebec for wastewater treatment and biodiesel production. Bioresource technology 157C: 140-148. 
[2] Abdel-Raouf, N., Al-Homaidan, A.A., Ibraheem, I.B.M. (2012): Microalgae and wastewater treatment. - Saudi Journal of Biological Sciences 19(3): 257-275.

[3] Andersen, R.A., (2005): Algal Culturing Techniques 1st Edition, Burlington, USA: ELSEVIER Academic Press.

[4] APHA (2012): Standard Methods for the Examination of Water and Wastewater. American Public Health Association, Washington.

[5] Ashokkumar, V. Rengasamy, R. (2012): Mass culture of Botryococcus braunii Kutz. under open raceway pond for biofuel production. - Bioresource technology 104: 394-9.

[6] Aslan, S., Kapdan, I.K. (2006): Batch kinetics of nitrogen and phosphorus removal from synthetic wastewater by algae. - Ecological Engineering 28(1): 64-70.

[7] Asmare, A.M., Demessie, B.A., Murthy, G.S. (2013): Baseline Study on the Dairy Wastewater Treatment Performance and Microalgae Biomass Productivity of an Open Pond Pilot Plant. - Ethiopian Case 4(4): 88-109.

[8] Asulabh, K.S., Supriya, G., Ramachandra, T.V. (2012): Effect of Salinity Concentrations on Growth Rate and Lipid Concentration in Microcystis Sp., Chlorococcum Sp. and Chaetoceros Sp. - In: National Conference on Conservation and Management of Wetland Ecosystems 06th. Kerala, India: Mahatma Gandhi University p. 27.

[9] Boonchai, R., Seo, G.T., Park, D.R., Seong, C.Y. (2012): Microalgae Photobioreactor for Nitrogen and Phosphorus Removal from Wastewater of Sewage Treatment Plant. International Journal of Bioscience, Biochemistry and Bioinformatics 2(6): 407-410.

[10] Brennan, L., Owende, P. (2010): Biofuels from microalgae-A review of technologies for production, processing, and extractions of biofuels and co-products. - Renewable and Sustainable Energy Reviews 14(2): 557-577.

[11] Cabanelas, I.T.D., Arbib, Z., Chinalia, F.A., Souza, C.O., Perales, J.A., Almeida, P.F., Druzian, D.I., Nascimento, I.A. (2013): From waste to energy: Microalgae production in wastewater and glycerol. - Applied Energy 109: 283-290.

[12] Cai, T., Park, S.Y., Li, Y. (2013): Nutrient recovery from wastewater streams by microalgae: Status and prospects. - Renewable and Sustainable Energy Reviews 19: 360-369.

[13] Can, S..S., Demir, V., Korkmaz, S.A., Can, E. (2013): Treatment of domestic waste water with Botryococcus braunii (Cholorophyceae). - Journal of Food, Agriculture and Environment 11(4\&3): 3-5.

[14] Chaput, G., Charmanski, K., Farag, I.H. (2012): Sustainable Production of Microalgae Oil Feedstock Using Municipal Wastewater and $\mathrm{CO} 2$ Fertilization. - International Journal of Engineering Science and Technology (IJEST) 4(07): 3489-3499.

[15] Cheng, P., Ji, B., Zhang, W., Wang, J., Liu, T. (2013): The growth, lipid and hydrocarbon production of Botryococcus braunii with attached cultivation. - Bioresource technology 138: 95-100.

[16] Choul-gyun, L., Kwangyong, L. (2002): Nitrogen Removal from Wastewaters by Microalgae Without Consuming Organic Carbon Sources. - Journal of Microbiology and Biotechnology 12(6): 979-985.

[17] Chu, F.-F., Chu, P-N., Shen, X-F., Lam, P.K.S., Zeng, R.J. (2014): Effect of phosphorus on biodiesel production from Scenedesmus obliquus under nitrogen-deficiency stress. Bioresource technology 152: 241-6.

[18] Creswell, L., (2010): Phytoplankton Culture for Aquaculture Feed, Florida, US. Available at: http://www2.ca.uky.edu/wkrec/PhytoplanktonAlgaeCulture.pdf.

[19] Dayananda, C., Sarada, R., Bhattacharya, S., Ravishankar, G.A. (2005): Effect of media and culture conditions on growth and hydrocarbon production by Botryococcus braunii. Process Biochemistry 40(9): 3125-3131.

[20] De la Noüe, J., Laliberté, G., Proulx, D. (1992): Algae and waste water. - Journal of Applied Phycology 4(3): 247-254.

[21] Environmental Quality Act, 1974. Department of Environmental, Malaysia. Available at: http://www.agc.gov.my/Akta/Vol.\%203/Act\%20127.pdf 
[22] Eroglu, E., Okada, S., Melis, A. (2011): Hydrocarbon productivities in different Botryococcus strains: comparative methods in product quantification. - Journal of applied phycology 23(4): 763-775.

[23] Gani, P., Sunar, N.M., Matias-Peralta, H., Abdul Latiff, A.A., Kamaludin, N.S., Parjo, U.K., Emparan, Q., Er, C.M. (2015a): Experimental Study for Phycoremediation of Botryococcus sp . on Greywater. - Applied Mechanics and Materials 773-774(2015): 1312-1317.

[24] Gani, P., Sunar, N.M., Matias-Peralta, H., Abdul Latiff, A.A., Joo, I.T.K., Parjo, U.K., Emparan, Q., Er, C.M. (2015b): Phycoremediation of Dairy Wastewater by Using Green Microalgae: Botryococcus sp. - Applied Mechanics and Materials 773774(2015): 1318-1323.

[25] Gani, P., Sunar, N.M., Matias-Peralta, H., Abdul Latiff, A.Z., Parjo, U.K., Abdul Razak, A.R. (2015c): Phycoremediation of Wastewaters and Potential Hydrocarbon from Microalgae : A Review. - Advances in Environmental Biology 9(20): 1-8.

[26] Guo, Z., Liu, Y., Guo, H., Mu, J. (2013): Microalgae cultivation using an aquaculture wastewater as growth medium for biomass and biofuel production. - Journal of environmental sciences (China) 25: S85-8.

[27] Issarapayup, K., Powtongsook, S., Pavasant, P. (2009): Flat panel airlift photobioreactors for cultivation of vegetative cells of microalga Haematococcus pluvialis. - Journal of biotechnology 142(3-4): 227-32.

[28] Ji, M.-K., Abou-Shanab, R-A.I., Kim, S-H., Salama, E-S., Lee, S-H., Kabra, A.N., Lee, Y-S., Hong, S., Jeon, B-H. (2013): Cultivation of microalgae species in tertiary municipal wastewater supplemented with $\mathrm{CO}_{2}$ for nutrient removal and biomass production. Ecological Engineering 58: 142-148.

[29] Karthikeyan, P., Manimaran, K., Sampathkumar, P., Rameshkumar, L. (2012): Growth and nutrient removal properties of the diatoms, Chaetoceros curvisetus and C. simplex under different nitrogen sources. - Applied Water Science 3(1): 49-55.

[30] Kim, T.H., Lee, Y., Han, S.H., Hwang, S.J. (2013): The effects of wavelength and wavelength mixing ratios on microalgae growth and nitrogen, phosphorus removal using Scenedesmus sp. for wastewater treatment. - Bioresource Technology 130: 75-80.

[31] Kirrolia, A., Bishnoi, N.R., Singh, R. (2012): Effect of shaking, incubation temperature , salinity and media composition on growth traits of green microalgae Chlorococcum sp .Journal of Algal Biomass Utilization 3(3): 46-53.

[32] Komolafe, O., Velasquez Orta, S.B., Monje-Ramirez, I., Yáñez Noguez, I., Harvey, A.P., Orta Ledesma, M.T. (2014): Biodiesel production from indigenous microalgae grown in wastewater. - Bioresource Technology 154: 297-304.

[33] Kothari, R., Pathak, V.V., Kumar, V., Singh, D.P. (2012): Experimental study for growth potential of unicellular alga Chlorella pyrenoidosa on dairy waste water: an integrated approach for treatment and biofuel production. - Bioresource Technology 116: 466-70.

[34] Kothari, R., Prasad, R., Kumar, V., Singh, D.P. (2013): Production of biodiesel from microalgae Chlamydomonas polypyrenoideum grown on dairy industry wastewater. Bioresource Technology 144: 499-503.

[35] Lim, J.X., Vadivelu, V.M. (2014): Treatment of agro based industrial wastewater in sequencing batch reactor: Performance evaluation and growth kinetics of aerobic biomass. - Journal of Environmental Management 146: 217-225.

[36] Mata, T.M., Melo, A.C., Simões, M., Caetano, N.S. (2012): Parametric study of a brewery effluent treatment by microalgae Scenedesmus obliquus. - Bioresource Technology 107: 151-8.

[37] Mata, T.M., Martins, A. A., Caetano, N.S. (2010): Microalgae for biodiesel production and other applications: A review. - Renewable and Sustainable Energy Reviews 14(1): 217-232. 
[38] Mehrabadi, A., Craggs, R., Farid, M. (2014): Wastewater treatment high rate algal ponds (WWT HRAP) for low-cost biofuel production. Bioresource Technology. Available at: http://linkinghub.elsevier.com/retrieve/pii/S096085241401606X.

[39] Molnár, I., Lopez, D., Wisecaver, J.H., Devarenne, T.P., Weiss, T.L., Pellegrini, M., Hackett, J.D. (2012): Bio-crude transcriptomics: gene discovery and metabolic network reconstruction for the biosynthesis of the terpenome of the hydrocarbon oil-producing green alga, Botryococcus braunii race B (Showa). - BMC Genomics 13:1-28.

[40] Mostafa, S.S.M., Shalaby, E.A., Mahmoud, G.I. (2012): Cultivating Microalgae in Domestic Wastewater for Biodiesel Production. - Notulae Scientia Biologicae 4(1): 56-65.

[41] Muñoz, R., Guieysse, B. (2006): Algal-bacterial processes for the treatment of hazardous contaminants: A review. - Water Research 40(15): 2799-2815.

[42] Onalo, J.I., Peralta, H.M.M., Mohamed Sunar, N. (2014): Growth of Freshwater Microalga, Botryococcus sp. in Heavy Metal Contaminated Industrial Wastewater. Journal of Science and Technology 6(2): 29-40.

[43] Órpez, R., Martínez, M.E., Hodaifa, G., El Yousfi, F., Jbari, N., Sánchez, S. (2009): Growth of the microalga Botryococcus braunii in secondarily treated sewage. Desalination 246(1-3): 625-630.

[44] Oswald (1957): Photosynthesis in Sewage Treatment. American Society of Civil Engineers - Transactions: 73-105.

[45] Park, J.B.K., Craggs, R.J., Shilton, a N. (2011): Wastewater treatment high rate algal ponds for biofuel production. - Bioresource technology 102(1): 35-42.

[46] Prakash, J., Bundschuh, J., Chen, C-Y., Bhattacharya, P. (2014): Microalgae for third generation biofuel production, mitigation of greenhouse gas emissions and wastewater treatment: Present and future perspectives - A mini review. - Energy (In Press): 1-10.

[47] Qin, Li (2006): Optimization of Growth Environment of Botryococcus braunii strain CHN 357. - Journal of Freshwater Ecology 21(1): 169-176.

[48] Ramachandra, T.V., Durga Madhab, M., Shilpi, S., Joshi, N.V. (2013): Algal biofuel from urban wastewater in India: Scope and challenges. - Renewable and Sustainable Energy Reviews 21: 767-777.

[49] Rasoul-Amini, S., Montazeri-Najafabady, N., Shaker, S., Safari, A., Kazemi, A., Mousavi, P., Mobasher, M.A., Ghasemi, Y. (2014): Removal of nitrogen and phosphorus from wastewater using microalgae free cells in bath culture system. - Biocatalysis and Agricultural Biotechnology 3(2): 126-131.

[50] Rawat, I., Ranjith Kumar, R., Mutanda, T., Bux, L. (2011): Dual role of microalgae: Phycoremediation of domestic wastewater and biomass production for sustainable biofuels production. - Applied Energy 88(10): 3411-3424.

[51] Sacristán de Alva, M., Luna-Pabello, V.M., Cadena, E., Ortíz, E. (2013): Green microalga Scenedesmus acutus grown on municipal wastewater to couple nutrient removal with lipid accumulation for biodiesel production. - Bioresource technology 146: 744-8.

[52] Shin, D.Y., Cho, H.U., Utomo, J.C., Choi, Y.-N., Xu, X., Park, J.M. (2015): Biodiesel production from Scenedesmus bijuga grown in anaerobically digested food wastewater effluent. - Bioresource technology 184:215-21.

[53] Sivakumar, R., Rajendran, S. (2013): Role of Algae in Commercial Environment. International Research Journal of Environment Sciences 2(12): 81-83.

[54] Slade, R., Bauen, A. (2013): Micro-algae cultivation for biofuels: Cost, energy balances, environmental impacts and future prospects. - Biomass and Bioenergy 53(0): 29-38.

[55] Suzuki, R., Ito, N., Uno, Y., Nishii, I., Kagiwada, S., Okada, S., Noguchi, T. (2013): Transformation of lipid bodies related to hydrocarbon accumulation in a green alga, Botryococcus braunii (Race B). - PloS one 8(12): e81626.

[56] Teles, I., Cabanelas, D., Ruiz, J., Arbib, Z., Alexandre, F., Garrido-pérez, C., Rogalla, F., Nascimento, I.A., Perales, J.A. (2013): Comparing the use of different domestic 
wastewaters for coupling microalgal production and nutrient removal Technology. Bioresource Technology 131:429-436.

[57] Udom, I., Zaribaf, B.H., Halfhide, T., Gillie, B., Dalrymple, O., Zhang, Q., Ergas, S.J. (2013): Harvesting microalgae grown on wastewater. - Bioresource Technology 139: 101-106.

[58] Wang, L., Min, M., Li, Y., Chen, P., Chen, Y., Liu, Y., Wang, Y., Ruan, R. (2010): Cultivation of green algae Chlorella sp. in different wastewaters from municipal wastewater treatment plant. - Applied Biochemistry and Biotechnology 162(4): 11741186.

[59] Wang, S.-K.K., Wang, F., Stiles, A.R., Guo, C., Liu, C-Z. (2014): Botryococcus braunii cells: ultrasound-intensified outdoor cultivation integrated with in situ magnetic separation. - Bioresource Technology 167: 376-382.

[60] Zhang, T.-Y., Wu, Y-H., Zhu, S-F., Li, F-M., Ho, H-Y. (2013): Isolation and heterotrophic cultivation of mixotrophic microalgae strains for domestic wastewater treatment and lipid production under dark condition. - Bioresource Technology 149: 586-9.

[61] Zhu, L., Wang, Z., Shu, Q., Takala, J., Hiltunen, E., Feng, P., Yuan, Z. (2013): Nutrient removal and biodiesel production by integration of freshwater algae cultivation with piggery wastewater treatment. - Water Research 47(13): 4294-302. 